\title{
RANCANGAN SISTEM INFORMASI PENDAFTARAN SISWA BARU BERBASIS WEB PADA SMK PUTRA RIFARA
}

\author{
Ainiyatul Maghfiroh ${ }^{1}$, Henderi $^{* 2}$, Giandari Maulani $^{3}$ \\ Mahasiswa Manajemen Informatika, Fakultas Sains dan Teknolologi, Universitas Raharja ${ }^{1}$ \\ Penulis Korespondensi, Dosen Pasca Sarjana Teknik Informatika, Universitas Raharja ${ }^{2}$ \\ Dosen Program Studi Sistem Informasi, Fakultas Sains dan Teknolologi Universitas \\ Raharja $^{3}$ \\ Jl. Jenderal Sudirman No. 40 Cikokol Kota Tangerang, Banten $15117^{1,2,4}$ \\ Su-rel: henderi@ raharja.info ${ }^{1}$, ainiyatul@ raharja.info², giandari@ raharja.info3
}

\begin{abstract}
New student registration is one of the processes that is normally carried out every year in educational institutions such as schools. New student registration is useful for screening prospective students who have been selected tobecome their students. In this research the process of registering new students at SMK Putra Rifara is done conventionally and has not been computerized, which allows many errors from writing data, stacking files and losing data. The formulation of the problem of this research is how to make a registration information system for SMK Putra Rifara. So the research method used is the method of observation, interviews, and library methods. The new student registration in formation system is buit with the PHP programming language and utilizes the MySQL database as a database server. The results of this study are web-based new student registration information systems that have the ability to provide data accuracy and ease for parents and prospective new students to obtain information about the school.
\end{abstract}

Keywords: Website, Information, Registration.

\begin{abstract}
Abstrak :Pendaftaran siswa baru merupakan salah satu proses yang biasa di laksanakan setiap tahunnya di lembaga pendidikan seperti sekolah. Pendaftaran siswa baru berguna untuk menyaring calon siswa yang terpilih untuk menjadi siswa didiknya. Dalam penelitian ini proses pendaftaran siswa baru pada SMK Putra Rifara dilakukan secara konvensional dan belum terkomputerisasi, yang memungkinkan banyak kesalahan dari penulisan data, penumpukan berkas dan kehilangan data. Rumusan masalah dari penelitian ini adalah bagaimana membuat sistem informasi pendaftaran SMK Putra Rifara. Metode penelitian yang digunakan yaitu dengan metode observasi, wawancara, dan metode pustaka. Sistem informasi pendaftaran siswa baru dibangun dengan bahasa pemrograman PHP serta memanfaatkan database MySQL sebagai database server. Hasil dari penelitian ini adalah sistem informasi pendaftaran siswa baru berbasis web yang memiliki kemampuan memberikan keakuratan data serta kemudahan bagi orang tua dan calon siswa baru untuk memperoleh informasi tentang sekolah
\end{abstract}

Kata kunci : Website, Informasi, Pendaftaran.

\section{PENDAHULUAN}

Perkembangan teknologi informasi telah memberikan banyak manfaat dalam kemajuan di berbagai aspek. Penerapan teknologi informasi dapat meningkatkan efektifitas dan efisiensi pekerjaan. Karena itu, teknolohi informasi banyak diterapkan oleh berbagai organisasi.
Pemanfaatan tersebut mempermudah suatu pekerjaan seperti pengolahan data dan keputusan yang diambil dapat lebih cepat terselesaikan, serta penghematan biaya dan waktu. Namun demikian, memenuhi kebutuhan masyarakat terhadap informasi yang cepat, tepat, dan akurat merupakan tantangan tersendiri bagi suatu instansi pendidikan baik formal maupun non 
formal [1]. Untuk itu, sistem informasi berbasis web perlu dimanfaatkan sebagai sarana memenuhi kebutuhan informasi yang dimaksud.

SMK Putra Rifara yang bergerak dibidang pendidikan berusaha untuk memberikan pelayanan yang terbaik untuk siswa/siswinya. Permasalahan yang terjadi pada SMK Putra Rifara adalah belum adanya website yang memudahkan calon siswa/siswi untuk melakukan pendaftaran siswa baru secara online. Proses pendaftaran siswa baru di SMK Putra Rifara masih bersifat konvensional dan belum terkomputerisasi. Sedangkan telah kita ketahui bersama, saat ini sistem-sistem yang ada dituntut agar lebih optimal, efisien, memiliki keakuratan, keamanan, ekonomis dan data tersebut dapat diakses secara tepat serta memiliki tempat penyimpanan data yang terjamin [2]. Sehingga SMK Putra Rifara membutuhkan sebuah sistem pendaftaran siswa baru dan pengolahan data yang berbasis website.

\section{METODE PENELITIAN}

Penelitian ini secara umum dilakukan menggunakan tahapan identifikasi permasalahan, identifikasi kebutuhan, desain sistem yang diusulkan, dan pengujian terhadap sistem. Identifikasi terhadap permasalahan dan kebutuhan dilakukan menggunakan pendekatan observasi, wawancara dan studi pustaka.

Pendekatan observasi digunakan karena pendekatan ini menakankan pada proses penelitian terhadap suatu sistem yang berjalan pada suatu lembaga guna mengetahui seberapa besar manfaat sistem bagi perusahaan [3].
Sementara metode wawancana digunakan untuk melengkapi data dan informasi yang belum didapatkan pada metode observasi.

Selain itu, identifikasi permasalahan dan kebutuhan juga dilakukan dengan pendekatan studi pustaka. Studi pustaka dilakukan terhadap penelitian-penelitian yang sudah ada dan berhubungan. Pada bagian lain, desain sistem dilakukan dengan pendekatan Unified Modeling Language (UML) [2]. Pendekatan ini dipilih dengan pertimbangan mudah dipahami dan menekankan kepada fungsional sistem yang dikembangkan.

\section{HASIL DAN PEMBAHASAN}

\subsection{Rancangan sistem yang diusulkan}

Langkah selanjutnya adalah merancang sistem pendaftaran siswa baru yang bertujuan untuk mempermudah calon siswa dalam mendaftar sekolah dan mempermudah pihak sekolah dalam pengolahan data dan pengambilan keputusan. Dengan menganalisa prosedur usulan yang baru pada penelitian, menggunakan aplikasi program Visual Paradigm for UML Enterprise Edition 6.4 UML yang berfungsi untuk menggambarkan use case diagram, acitivity diagram, sequence diagaram, dan class diagram.

\section{Use Case Diagram Pendaftaran Siswa}

Use case diagram digunakan untuk menggambarkan interaksi antara actor dan use case pada sistem perangkat lunak yang akan dikembangkan [4]. Gambar 1 menunjukan aktifitas pada sistem pendaftaran siswa baru. Secara umum aktifitas terdiri dari : calon siswa 
melihat profile SMK Putra Rifara melalui web untuk mendapatkan informasi mengenai sekolah pada sistem yang diusulkan melalui fungsi Home, Tentang, dan Ekstrakulikuler

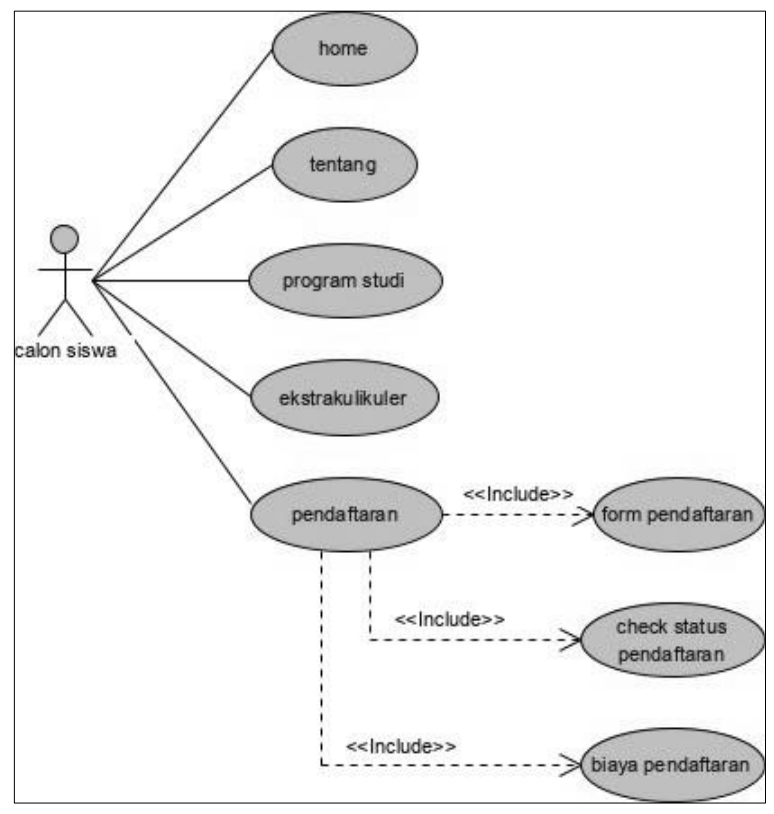

\section{Gambar 1. Use Case Diagram Pendaftaran}

Pengisian data diri siswa baru pada sistem dilakukan melalui fungsi Form Pendaftaran. Penginputan data pada form perndaftaran yang diusulkan bertujuan untuk memberikan keakuratan data calon siswa baru.

\section{Use Case Diagram Pengelolaan Sistem Pendaftaran Siswa}

Gambar 2 menunjukan aktifitas pada pengelolaan sistem pendaftaran siswa baru. Secara umum aktifitas terdiri dari login, dashboard, data pendaftar, data siswa, daftar siswa di terima, daftar siswa ditolak, laporan pendaftaran siswa, dan logout.

Pengelolaan data pada sistem yang diusulkan bertujuan untuk memberikan keakuratan data, kemudahan dalam mencari data siswa, dan menghindari kehilangan data, sehingga keamanan data terjamin karena data tersimpan di database.

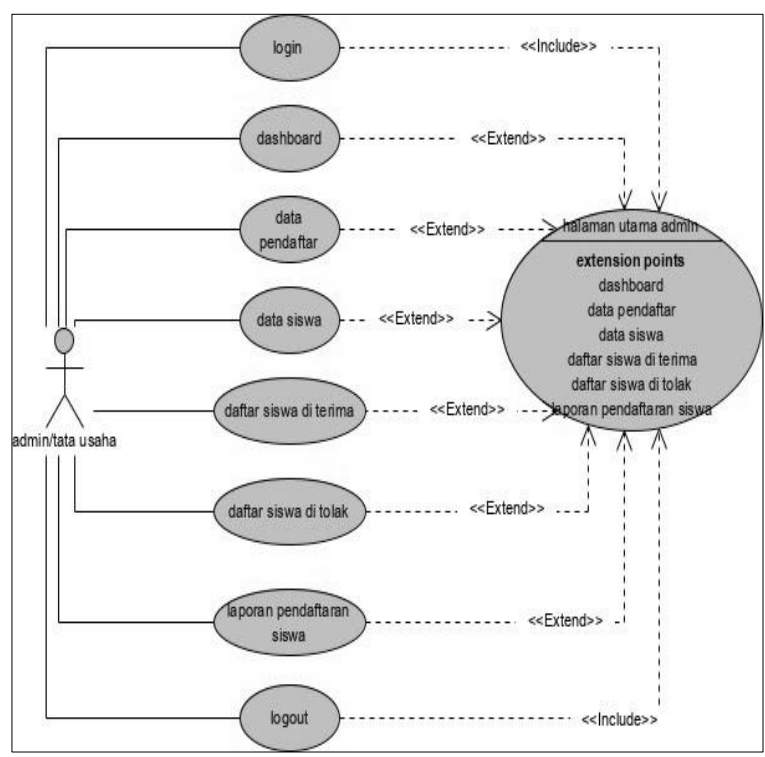

Gambar 2. Use Case Diagram Pengelolaan Sistem Pendaftaran Siswa

\section{Activity Diagram Pendaftaran Siswa}

Activity diagram adalah sesuatu yang menggambarkan berbagai alir aktivitas dalam sistem yang sedang dirancang [5].

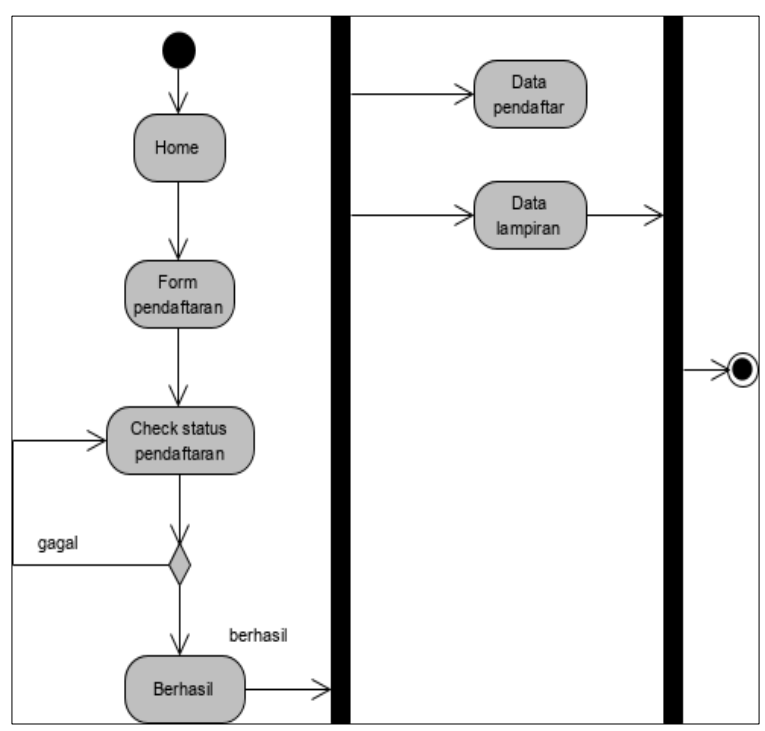

Gambar 3. Activity Diagram Pendaftaran Siswa 
Gambar 3 menunjukan aktifitas pendaftaran pada sistem yang dikembangkan. Aktifitas yang di lakukan yaitu calon siswa membuka web maka akan muncul di Home, calon siswa mengisi data diri di menu Form Pendaftaran, setelah mengisi form pendaftaran selanjutnya calon siswa mengecek statusnya di menu Check Status dengan login menggunakan NISN, jika calon siswa di terima maka calon siswa dapat melihat data diri dan dapat mencetak formulir yang sudah diisi. Aktifitas ini dapat memudahkan siswa untuk daftra dimana saja dan kapan saja tanpa harus datang langsung ke sekolah dan meminimalisir kesalahan dalam penginputan data.

\section{Activity Diagram Pengelolaan Sistem}

\section{Pendaftaran Siswa}

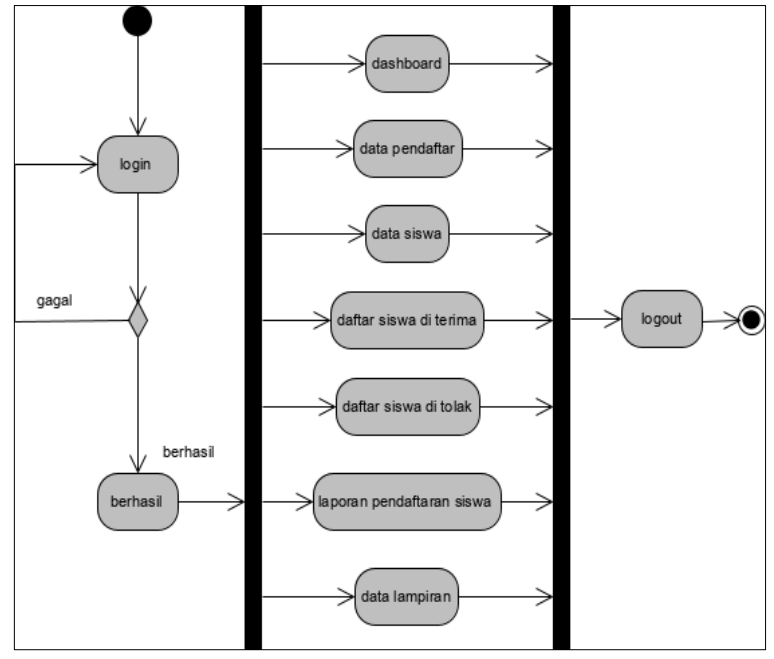

Gambar 4. Activity Diagram Pengelolaan

\section{Sistem Pendaftaran Siswa}

Gambar 4 menunjukan aktifitas yang pada pengelolaan sistem pendaftaran siswa baru. Secara umum sistem akan berjalan : admin login terlebih dahulu, setelah admin login maka sistem akan menampilkan dashboard, data pendaftar, data siswa, daftar siswa di terima, daftar siswa di tolak, laporan pendaftaran siswa, dan lampiran yang dapat di kelola oleh admin. Di sistem ini seluruh data siswa akan tersimpan dengan aman karena data tersimpan di database sehingga tidak terjadi kehilangan data dan data yang diperlukan akan lebih mudah di temukan.

\section{Sequence Diagram Pendaftaran Siswa}

Sequence diagram menggambarkan interaksi antar obyek di dalam dan di sekitar sistem (termasuk pengguna dan display) berupa message yang digambarkan terhadap waktu.

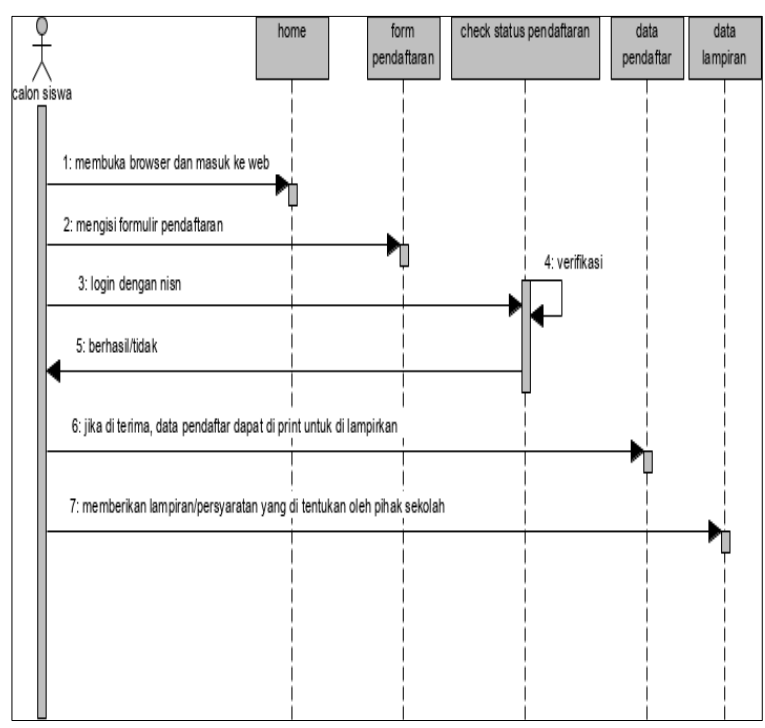

Gambar 5 Sequence Diagram Pendaftaran

\section{Siswa}

Gambar 5 menunjukan aktifitas yang terdapat pada sistem pendaftaran siswa. Aktifitas pendaftaran terdiri dari: membuka browser dan masuk ke web, mengisi formulir pendaftaran, dan login dengan nisn. Jika berhasil maka sistem menampilkan data diri serta keterangan calon siswa apakah di terima/tidak. Calon siswa yang di terima dapat mencetak formulir pendaftaran untuk dilampirkan beserta persyaratan pendaftaran yang sudah di tentukan. 


\section{Class Diagram Pendaftaran Siswa}

Class adalah sebuah spesifikasi yang jika diinstansiasi akan menghasilkan sebuah objek dan merupakan inti dari pengembangan dan desain berorientasi objek [2].

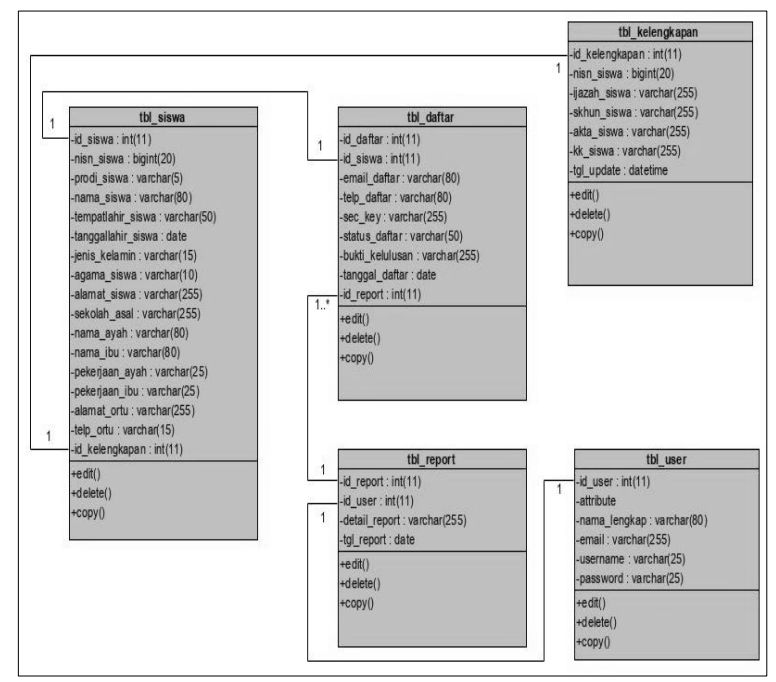

Gambar 6 Class Diagram

Gambar 6 menunjukan bahwa sistem yang dikembangkan memiliki lima class. Kelima class tersebut berfungsi untuk menyimpan data-data objek yang penting dan akan dianalisis.

\subsection{Tampilan Sistem Pendaftaran Siswa}

Tahapan ini merupakan gambaran sistem yang akan di usulkan pada pendaftaran siswa baru:

\section{Tampilan Menu Home}

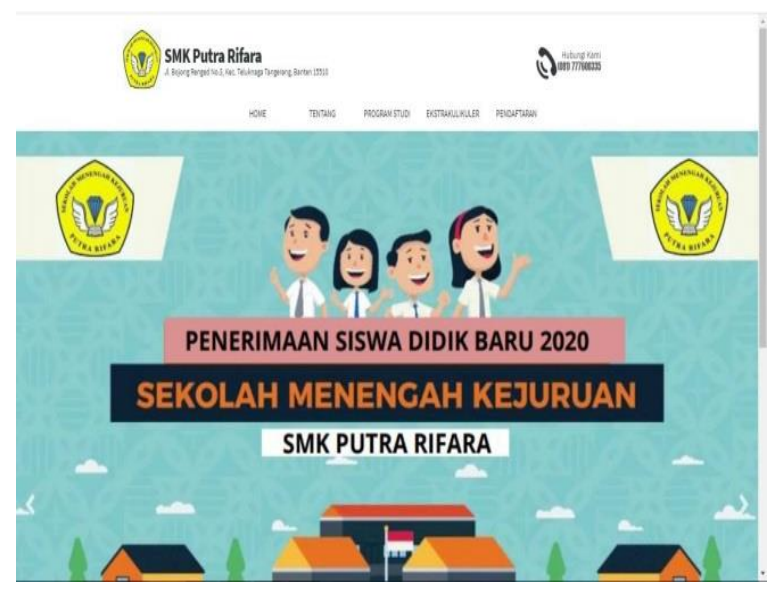

Gambar 7. Tampilan Menu Home
Gambar 7 merupakan tampilan menu home yang berfungsi untuk melihat menu-menu yang ada di website. Seperti menu Tentang berisi profil dan visi-misi dari SMK Putra Rifara, menu Prodi, menu Ekstrakulikuler dan menu Pendaftaran. Hal ini dapat memberikan kemudahan bagi orang tua dan calon siswa baru untuk memperoleh informasi tentang sekolah.

\section{Tampilan Menu Formulir Pendaftaran}

Tampilan formulir pendaftaran yang diisi oleh calon siswa ditunjukan di Gambar 8. Formulir pendaftaran bisa diisi dan dilengkapi oleh calon siswa dari mana saja dan kapan saja. Hal ini dapat mempercepat pendataan terhadap calon siswa. Formulir pendaftaran siswa baru secara online ini memecahkan permasalahan pada sistem yang berjalan dalam hal pendataan calon siswa yang masih manual atau belum terkomputerisasi.

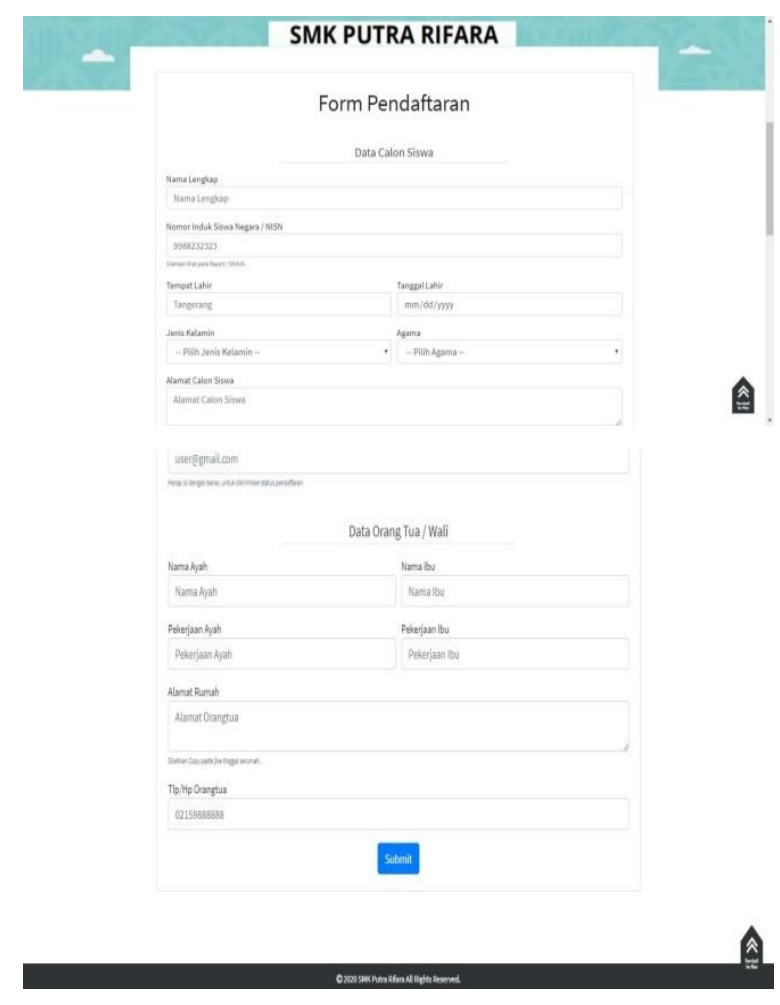

Gambar 8. Tampilan Formulir Pendaftaran 


\section{Tampilan Dashboar Admin}

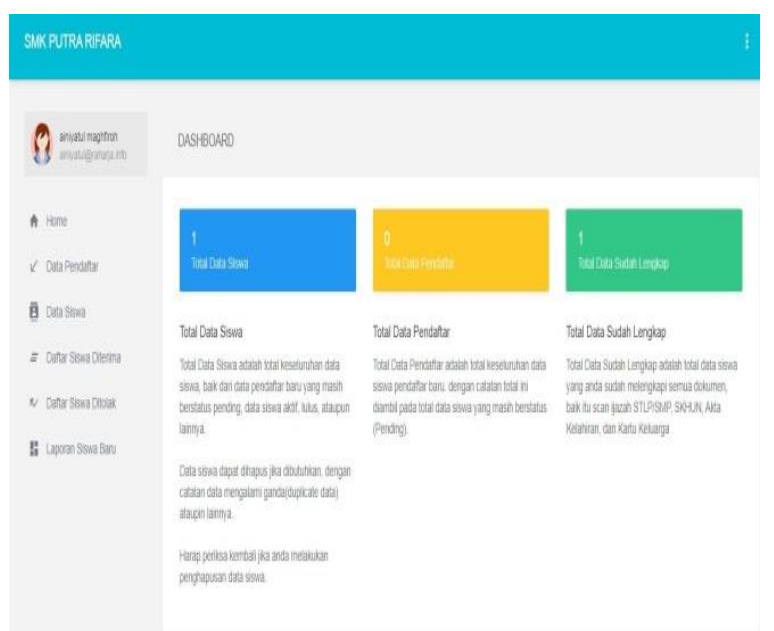

\section{Gambar 9. Tampilan Dashboard}

Gambar ini berisi dashboard admin yang terdapat Total Data Siswa, Total Data pendaftar, dan Total Data Sudah Lengkap.

\section{Tampilan Data Pendaftar pada Admin}

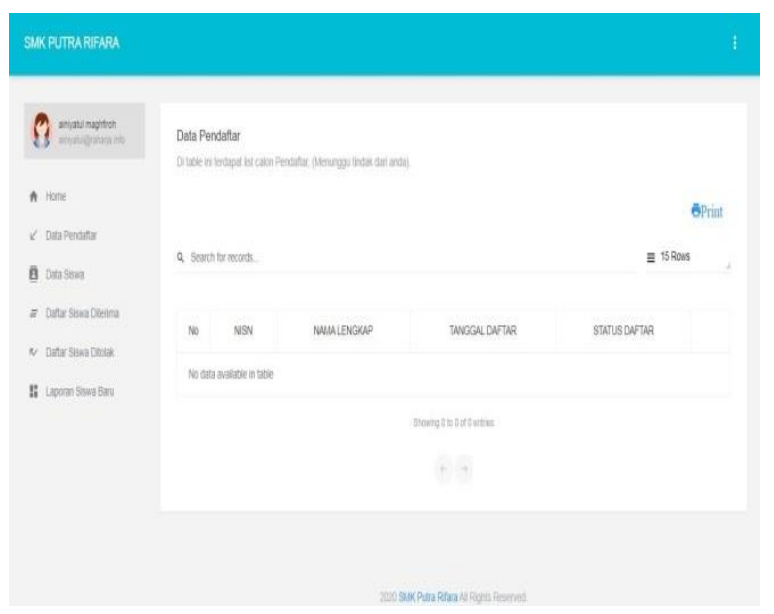

\section{Gambar 10. Tampilan Data Pendaftar}

Gambar ini merupakan tampilan data pendaftar untuk calon siswa yang sudah mendaftar melalui web pendaftaran siswa baru.

\section{Tampilan Data Siswa pada Admin}

Gambar 11 merupakan tampilan dari seluruh data siswa yang sudah menjadi siswa di SMK Putra Rifara. Pada sistem ini, admin mengelola data siswa yang berupa berkas-berkas persyaratan dari pendaftaran siswa baru. Sehingga data siswa baru tersimpan dengan aman di dalam database dan apabila data diperlukan maka mudah dalam pencariannya.

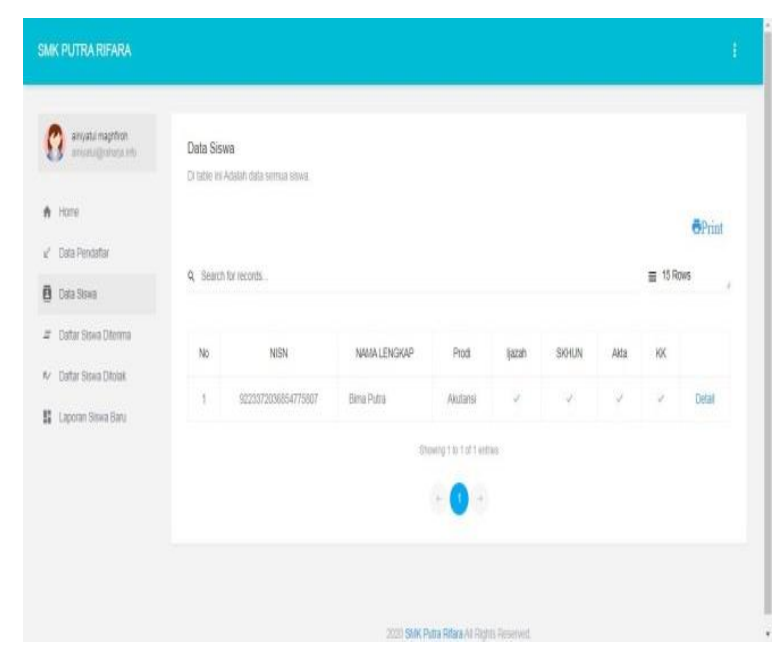

\section{Gambar 11. Tampilan Data Siswa}

\section{Tampilan Laporan Pendaftaran Siswa Baru}

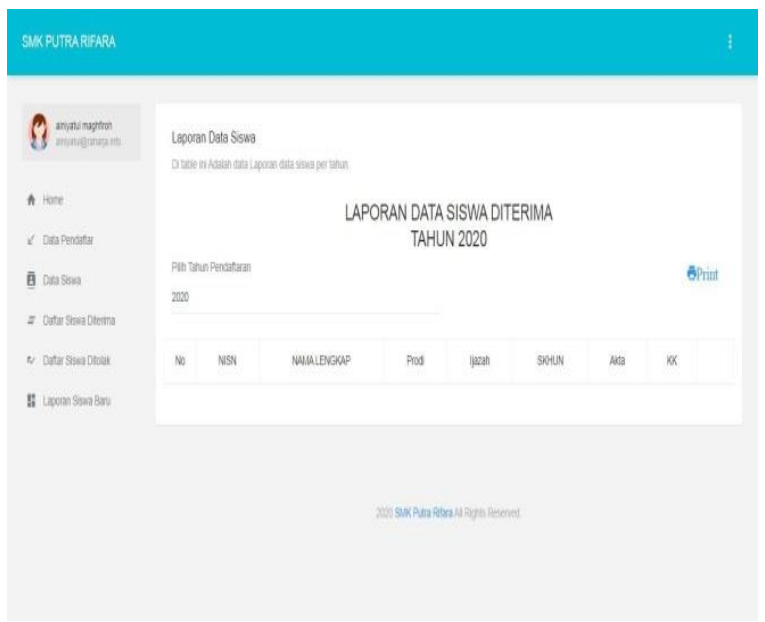

\section{Gambar 12. Tampilan Laporan Pendaftaran}

Gambar 12 merupakan tampilan dari laporan pendaftaran siswa baru, seluruh data pendaftar yang di terima maupun di tolak akan masuk kedalam laporan pendaftaran siswa baru yang akan diserahkan kepada kepala sekolah. Laporan pendaftraan siswa baru dapat mendukung Kepala Sekolah mengambil 
keputusan tentang penerimaan siswa baru pada tahun berikutnya. Hal ini dapat memudahkan admin dalam mengerjakan tugasnya dan mendapat keakuratan data yang real serta keputusan yang diambil dapat lebih cepat terselesaikan.

Laporan yang dihasilkan di penelitian ini berbeda dengan penelitian yang dilakukan oleh Handayani, dkk [6] karena lebih detail dan dapat dijadikan pendukung keputusan oleh Kepala Sekolah. Di bagian lain, laporan yang dihasilkan pada sistem yang dikembangkan di penelitian ini menguatkan hasil penelitian Anggraini dengan tema yang sama yaitu Perancangan Website Pnerimaan Siswa Baru dengan Mengggunakan Metode Waterfall.

\section{KESIMPULAN}

Rancangan sistem informasi pendaftaran siswa baru yang dihasilkan melalui penelitian ini memiliki beberapa keuntungan. Diantaranya, menghemat biaya yang dikeluarkan oleh calon siswa baru dan pihak sekolah, memudahkan pencarian data siswa baru yang mendaftar, dan keamanan data calon siswa yang mendaftar lebih aman. Implementasi terhadap rancangan sistem informasi pendaftaran siswa baru pada penelitian ini juga medukung kepala sekolah mengambil keputusan tentang pendaftaran siswa baru.

\section{DAFTAR PUSTAKA}

[1] Herliana, A., \& Rasyid, P. M. (2016). Sistem Informasi monitoring pengembangan software pada tahap development berbasis web. Jurnal Informatika, 3 (1).

[2] Profesi, D. E., \& Henderi, H. Analisis dan Perancangan Sistem Informasi Kepegawaian Menggunakan Unified Modeling Language (UML). Jurnal Sistem Informasi dan Teknologi Informasi, 7 (1), 22-33.

[3] Rahardja, U., Aini, Q., \& Thalia, M. B. (2018). Penerapan Menu Konfirmasi Pembayaran Online Berbasis Yii pada Perguruan Tinggi. Creative Information Technology Journal, 4 (3), 174-185.

[4] Husain, A., Prastian, A. H. A., \& Ramadhan, A. (2017). Perancangan Sistem Absensi Online Menggunakan Android Guna Mempercepat Proses Kehadiran Karyawan Pada PT. Sintech

[5] Mahdiana, D. (2016). Analisa dan rancangan sistem informasi pengadaan barang dengan metodologi berorientasi obyek: studi kasus PT. Liga Indonesia. Telematika MKOM, 3 (2), 36-43.

[6] Handayani, I., Aini, Q., Cholisoh, N., \& Agustina, I. I. (2018). Pemanfaatan Google Form Sebagai Pendaftaran TOEFL (Test Of English as a Foreign Language) Secara Online. Jurnal Teknoinfo, 12 (2), 55-59.

[7] Anggraini, I. (2019). Perancangan Website Penerimaan Siswa Baru Dengan Menggunakan Metode Waterfall. Jurnal Ilmiah Binary, STMIK Bina Nusantara Jaya Lubuk linggau, 1 (2), 56-62 